\title{
Implementasi Kooperatif NHT Meningkatkan Aktivitas Dan Hasil Belajar Teknik Dasar Passing Kaki Bagian Luar
}

\author{
I Komang Dwi Astika', I Gusti Lanang Agung Parwata, I Komang Wirasuta \\ 1Jurusan Pendidikan Jasmani, Kesehatan, dan Rekreasi, \\ Fakultas Olahraga dan Kesehatan, \\ Universitas Pendidikan Ganesha \\ Singaraja, Indonesia \\ e-mail: $\left\{\right.$ astikadwi86@gmail.com ${ }^{1}$ agung.parwata@undiksha.ac.id\} \\ @undiksha.ac.id
}

\begin{abstract}
Abstrak
Penelitian ini bertujuan meningkatkan aktivitas dan hasil belajar passing melalui penerapan model pembelajaran kooperatif tipe NHT. Subjek penelitian ini siswa kelas XII MIPA 8 SMA Negeri 1 Singaraja, yang berjumlah 32 orang. Data dianalisis menggunakan statistik deskriptif. Berdasarkan hasil penelitian didapatkan rata-rata aktivitas belajar passing kaki bagian luar, secara klasikal pada observasi awal 6,2 (cukup aktif), meningkat pada siklus I menjadi 7,14 (aktif), dan meningkat pada siklus II menjadi 7,92 (aktif). Sedangkan persentase kentuntasan hasil belajar secara klasikal pada observasi awal $20 \%$, meningkat pada siklus I menjadi $84 \%$, dan meningkat pada siklus II menjadi $100 \%$. Berdasarkan hasil analisis dan pembahasan, dapat disimpulkan bahwa aktivitas dan hasil belajar passing menggunakan kaki bagian luar sepakbola meningkat melalui penerapan model pembelajaran NHT pada siswa kelas XII MIPA 8 SMA Negeri 1 Singaraja. Disarankan kepada guru PJOK untuk menerapkan model pembelajaran NHT karena meningkatkan aktivitas dan hasil belajar passing menggunakan kaki bagian luar siswa.
\end{abstract}

Kata-kata kunci: NHT, aktivitas, hasil belajar, passing.

\begin{abstract}
This research aims to improve the activity and the result study of passing foot ball through the implementation of type of cooperative model NHT to XII MIPA 8 grade students of SMAN 1 Singaraja, in which the population are 32 students. The data were analyzed by descriptive statistic. Based on this research, from the first observation the mean of activity of passing football in classical way is 6,2 (enough active) the improvement in cycle I is 7,14 (active) and in the cycle II to be 7,92 (active). Whereas percentage the result in the classical from the first observation is $20 \%$, it improves in cycle I to be $84 \%$ and in cycle II, the improvement is $100 \%$. Based on the data analysis and the explanation above, it can be conclude that the activity and the result study of passing foot ball are improved through the implementation of type of cooperative study that is in XII MIPA 8 grade students of SMAN 1 Singaraja. The suggestion to the teacher who teach sport in to implement the type of cooperative model $\mathrm{NHT}$ to improve the activity and the result study of students in passing foot ball.
\end{abstract}

Key words: NHT, Activity, Result study, passing.

\section{Pendahuluan}

Peningkatan kualitas pembelajaran merupakan salah satu upaya yang dilakukan untuk meningkatkan mutu pendidikan, disamping dengan pengadaan sarana dan prasarana yang memadai, sumber dan bahan ajar, serta penyempurnaan kurikulum. Selain itu, dari segi model-model pembelajaran yang harus direncanakan sesuai dengan situasi dan kondisi siswa saat ini. Model pembelajaran sangat diperlukan untuk memandu proses belajar secara efektif. Namun, segala sesuatu tidak hanya bersumber dari guru melainkan juga peran aktif siswa di dalamnya. Sehingga hal ini, secara tidak langsung akan menjadi nilai lebih didalam meningkatkan potensi yang dimiliki siswa.Pada pelajaran PJOK terutama di SMA, siswa cenderung kurang aktif untuk berpartisipasi dalam proses pembelajaran, hal ini terbukti dari aktvitas dan hasil belajar gerak yang diperoleh siswa kurang memuaskan atau belum 
memenuhi sasaran yang ditunjukkan dengan belum dikuasainya teknik-teknik gerak yang diajarkan. Siswa cenderung menyepelekan pelajarn PJOK, sebab mereka lebih terkonsentrasi pada mata pelajaran yang diujikan pada ujian nasional. Depdiknas, (2006: 163) menyatakan, pendidikan jasmani, olahraga dan kesehatan (penjasorkes) merupakan bagian integral dari pendidikan yang secara keseluruhan, bertujuan untuk mengembangkan aspek kebugaran jasmani, keterampilan gerak, keterampilan berpikir kritis, keterampilan sosial, penalaran, setabilitas emosional, tindakan moral, aspek pola hidup sehat, dan pengenalan lingkungan bersih melalui aktivitas jasmani, olahraga dan kesehatan terpilih yang direncanakan secara sistematis dalam rangka mencapai tujuan pendidikan nasional.

Berdasarkan hasil observasi awal yang dilakukan peneliti pada hari Rabu, 29 Agustus di kelas XII MIPA 8 SMA Negeri 1 Singaraja tahun pelajaran 2018/2019, aktivitas belajar 32 peserta didik (18 peserta didik perempuan dan 14 peserta didik laki-laki) pada materi teknik dasar passing sepak bola kaki bagian luar yang diperoleh pada saat observasi tergolong cukup aktif. Dapat dilihat dari komponen aktivitas belajar peserta didik yang terdiri dari kegiatan visual, lisan, mendengarkan, metrik, mental dan emosional. Berdasarkan hasil pengamatan dari keenam komponen aktivitas tersebut didapatkan hasil persentase sebagai berikut: Peserta didik pada kategori sangat aktif tidak ada (0\%), 14 orang $(46,7 \%)$ berada dalam kategori tingkat aktivitas yang aktif, 12 orang $(33,3 \%)$ berada dalam kategori tingkat aktivitas yang cukup aktif, 6 orang $(20 \%)$ berada dalam kategori tingkat aktivitas yang kurang aktif, dan tidak ada orang $(0 \%)$ berada dalam kategori tingkat aktivitas yang sangat kurang aktif, dengan persentase ketuntasan 14 orang $(46,7 \%)$ tuntas dan 18 orang $(53,3 \%)$ tidak tuntas. Berdasarkan data di atas, maka peneliti bisa mengetahui rata-rata klasikal aktivitas belajar teknik dasar passing kaki bagian luar sebesar 6,2 yang tergolong dalam kategori cukup aktif. Sehingga dapat diketahui berapa banyak peserta didik yang tuntas dan peserta didik tidak tuntas.

Jika dilihat dari hasil observasi, ketuntasan hasil belajar untuk aspek pengetahuan, peserta didik yang berada pada kategori baik 8 orang (20\%), dan pada kategori cukup baik 24 orang (80\%). Jadi jumlah siswa yang tuntas dalam Teknik Dasar Passing Kaki Bagian Dalam aspek pengetahuan secara klasikal yaitu 8 orang (20\%) tuntas dan 24 orang $(80 \%)$ tidak tuntas, dengan presentase nilai rata-rata hasil belajar secara klasikal yaitu $80 \%$ yang berada pada kategori tidak tuntas. Dengan menganalisa data hasil belajar kompetensi pengetahuan peserta didik secara keseluruhan terlihat belum memenuhi sasaran, karena belum memenuhi standar kriteria ketuntasan minimal (KKM) sekolah untuk mata pelajaran PJOK sebesar $82 \%$ ketuntasan klasikal. Permasalahan yang muncul pada aspek pengetahuan adalah kurangnya pemahaman peserta didik mengenai teknik dasar passing kaki bagian luar, hal ini disebabkan oleh kurangnya perhatian peserta didik pada saat guru menjelaskan dan pembelajaran masih dominan guru yang lebih aktif. Ketuntasan hasil belajar untuk aspek keterampilan, peserta didik yang berada pada kategori baik sebanyak 10 orang $(26,7 \%)$, cukup baik sebanyak 16 orang $(53,3 \%)$ dan kurang baik sebanyak 6 orang (20\%). Jadi jumlah siswa yang tuntas dalam teknik dasar passing kaki bagian luar aspek keterampilan secara klasikal yaitu 10 orang $(26,7 \%)$ tuntas dan 22 orang $(73,3 \%)$ tidak tuntas, dengan presentase nilai rata-rata hasil belajar secara klasikal yaitu $73,3 \%$ yang berada pada kategori tidak tuntas. Dengan menganalisa data hasil belajar kompetensi keterampilan peserta didik secara keseluruhan terlihat hasil belajar kompetensi keterampilan belum memenuhi target, karena belum memenuhi standar KKM sekolah untuk mata pelajaran PJOK sebesar $82 \%$ ketuntasan klasikal.

Jadi jumlah siswa yang tuntas dalam teknik dasar passing kaki bagian luar aspek sikap secara klasikal yaitu 7 orang $(16,7 \%)$ tuntas dan 25 orang $(83,3 \%)$ tidak tuntas, dengan presentase nilai rata-rata hasil belajar secara klasikal yaitu $83,3 \%$ yang berada pada kategori tuntas. Dengan menganalisa data hasil belajar kompetensi sikap peserta didik secara keseluruhan terlihat sudah memenuhi ketuntasan, karena sudah memenuhi standar KKM sekolah untuk mata pelajaran PJOK sebesar $82 \%$ ketuntasan klasikal. Jadi adanya peserta didik yang bermasalah pada hasil belajar disebabkan oleh (1) dari segi kerjasama, peserta didik masih kurang untuk melakukan kerjasama didalam pembelejaran dan 
cenderung individual, (2) dari segi disiplin, peserta didik masih banyak yang berpakaian kurang rapi, terlambat saat datang dan melakukan kegiatan diluar materi saat pembelajaran, (3) dari segi tanggung jawab, peserta didik kurang bertanggung jawab didalam pemakain sarana pembelajaran.

Jika dilihat dari rata-rata aktivitas dan hasil belajar teknik dasar passing kaki bagian luar di atas dapat disimpulkan bahwa, aktivitas dan hasil belajar teknik dasar passing kaki bagian luar pada kelas XII MIPA 8 SMA Negeri 1 Singaraja tidak tuntas. Hal ini disebabkan implementasi model pembelajaran yang belum efektif terhadap materi yang disajikan. Model pembelajaran yang diimplementasikan belum melibatkan atau merangsang peserta didik untuk lebih aktif dan kreatif selama proses pembelajaran berlangsung. Berdasarkan permasalahan di atas, peneliti mencoba memberikan salah satu alternatif pemecahan masalah yaitu dengan menerapkan model pembelajaran kooperatif tipe Numbered Head Together (NHT) dalam pembelajaran PJOK pada materi teknik dasar passing kaki bagian luar. Ketertarikan peneliti menerapkan model pembelajaran kooperatif tipe NHT ini karena (1) model pembelajaran kooperatif dengan tipe NHT adalah model pembelajaran yang sederhana, sehingga model pembelajaran kooperatif ini cocok diterapkan pada peserta didik kelas XII MIPA 8 SMA Negeri 1 Singaraja yang belum pernah melakukan pembelajaran kooperatif tipe NHT, (2) pada model pembelajaran ini peserta didik lebih banyak mempunyai kesempatan diskusi kelompok, masing-masing peserta didik memberikan partisipasinya secara maksimal dan setiap peserta didik mempunyai tanggung jawab perseorangan untuk menguasai materi dengan sebaik-baiknya, (3) model pembelajaran kooperatif dengan tipe NHT mengajak peserta didik untuk belajar aktif dan berani dalam mengeluarkan pendapat dalam diskusi kelompok. Apabila ada suatu konsep yang belum dimengerti dan dipahaminya, peserta didik dapat saling isi mengisi dengan peserta didik lain, saling bertukar pikiran sehingga diharapkan konsep yang dimiliki peserta didik benar-benar dapat dipahami dengan baik. Suasana belajar akan lebih kondusif, yang akhirnya berpengaruh terhadap aktivitas dan hasil belajar.

Pemilihan tentang model pembelajaran NHT ini juga dikuatkan oleh hasil penelitian dari peneliti-peneliti sebelumnya diantaranya (1) Penelitian yang dilakukan oleh Sanjaya, I.P.E.Y (2013 :123) dalam skripsinya yang menyimpulkan motivasi dan hasil belajar teknik Lompat jauh gaya menggantungmeningkat melalui penerapan model pembelajaran kooperatif tipe NHT pada peserta didik kelas X.5 SMA Negeri 1 Negara tahun pelajaran 2012/2013, (2) Penelitian yang dilakukan oleh Bawa, I.M.L (2012:116) dalam skripsinya yang menyimpulkan aktivitas dan hasil belajar teknik dasar passing sepak bola meningkat melalui penerapan model pembelajaran kooperatif tipe NHT pada peserta didik kelas X.1 SMK Negeri 2 Singaraja tahun pelajaran 2011/2012, (3) Penelitian yang dilakukan oleh Tirtawati, N.W (2013:103) dalam skripsinya yang menyimpulkan motivasi dan hasil belajar lompat jauh gaya menggantungmeningkat melalui penerapan model pembelajaran kooperatif tipe NHT pada peserta didik kelas XI IPA 3SMA Negeri 2 Bangli tahun pelajaran 2012/2013.

Berdasarkan uraian di atas, maka peneliti bermaksud mengadakan penelitian dengan judul "Implementasi Model Pembelajaran Kooperatif Tipe NHT untuk Meningkatkan Aktivitas dan Hasil Belajar Teknik Dasar Passing Kaki Bagian Luar pada Peserta Didik Kelas XII MIPA 8 SMA Negeri 1 Singaraja Tahun Pelajaran 2018/2019".

\section{Metode Penelitian}

Jenis penelitian yang digunakan adalah penelitian tindakan kelas. Menurut Arikunto dkk, (2008: 2-3) dikarenakan ada tiga kata yang membentuk pengertian tersebut, maka ada tiga pengertian yang dapat diterangkan sebagai berikut. (1) Penelitian, menunjuk pada suatu kegiatan mencermati suatu objek dengan menggunakan cara dan aturan metodologi tertentu untuk memproleh data atau informasi yang bermaanfat dalam meningkatkan mutu suatu hal yang menarik minat dan penting bagi peneliti, (2) Tindakan, menunjuk pada 
sesuatu gerak kegiatan yang disengaja dilakukan dengan tujuan tertentu, (3) Kelas, dalam hal ini tidak terikat pada pengertian ruang kelas, tetapi dalam pengertian yang lebih spesifik. Dapat disimpulkan bahwa penelitian tindakan kelas merupakan suatu pencermatan terhadap kegiatan belajar berupa sebuah tindakan, yang sengaja dimunculkan dan terjadi dalam sebuah kelas secara bersama.

Oja dan Smulyan membedakan adanya empat bentuk penelitian tindakan, yaitu (1) guru sebagai peneliti, (2) penelitian Tindakan Kolaboratif, (3) simultan-Terintregasi, (4) administrasi Sosial Eksperimental (Kanca, I Nyoman, 2010: 115). Dalam penelitian ini bentuk penelitian tindakan yang digunakan adalah guru sebagai peneliti. Karena peneliti sudah menjadi guru, maka dalam penelitian ini menggunakan bentuk penelitan peneliti sebagai guru, karena dalam bentuk PTK yang memandang guru sebagai peneliti mempunyai ciri-ciri penting yaitu sangat berperannya guru itu sendiri dalam proses PTK. Tujuan utama PTK adalah untuk memperbaiki dan meningkatkan mutu profesional guru didalam proses pembelajaran.

\section{Hasil Dan Pembahasan}

Penelitian ini dilaksanakan dari hari rabu tanggal 29 Agustus 2018 sampai dengan hari Sabtu tanggal 19 September 2018, yang dilaksanakan setiap pukul 05.30-07.45 wita, bertempat di lapangan upacara SMA Negeri 1 Singaraja, dengan subjek penelitiannya adalah peserta didik kelas XII MIPA 8 SMA Negeri 1 Singaraja Tahun Pelajaran 2018/2019 yang berjumlah 32 orang yang terdiri dari 14 orang peserta didik putra dan 18 orang peserta didik putri. Penelitian ini dilaksanakan sebanyak dua siklus, disetiap siklus terdapat dua kali pertemuan. Siklus I pertemuan pertama dilaksanakan pada hari rabu 29 Agustus 2018 untuk pengambilan data aktivitas belajar peserta didik dan pertemuan kedua dilaksanakan pada hari rabu 5 September 2018 untuk pengambilan data aktivitas dan hasil belajar peserta didik. Sedangkan siklus II pertemuan pertama dilaksanakan pada hari rabu 12 September 2018 untuk pengambilan data aktivitas belajar peserta didik dan pertemuan kedua dilaksanakan pada hari Rabu 19 september 2018 untuk pengambilan data aktivitas dan hasil belajar peserta didik, yang bertempat di lapangan Umum Mayor Metra, untuk pengambilan data aktivitas dan hasil belajar peserta didik melibatkan seorang Observer yaitu guru PJOK SMA Negeri 1 Singaraja.

Tabel 1. Hasil Analisis Data Aktivitas Belajar Teknik Dasar Passing Kaki Bagian Luar

\begin{tabular}{|c|c|c|c|c|c|}
\hline No & Kriteria & $\begin{array}{c}\text { Jumlah } \\
\text { Peserta } \\
\text { Dididk }\end{array}$ & Persentase & Kategori & Keterangan \\
\hline 1 & $\bar{X} \geq 9$ & - & - & Sangat aktif & \multirow{5}{*}{$\begin{array}{l}23 \text { Orang } \\
\text { Peserta Dididk } \\
\text { Aktif }(78 \%) \\
7 \text { Orang } \\
\text { Peserta Didik } \\
\text { Tidak Aktif } \\
(22 \%)\end{array}$} \\
\hline 2 & $7 \leq \bar{X}<9$ & 25 & $78 \%$ & Aktif & \\
\hline 3 & $5 \leq \bar{X}<7$ & 7 & $22 \%$ & Cukup Aktif & \\
\hline 4 & $3 \leq \bar{X}<5$ & - & - & Kurang Aktif & \\
\hline 5 & $\bar{X}<3$ & - & - & $\begin{array}{c}\text { Sangat Kurang } \\
\text { Aktif }\end{array}$ & \\
\hline & Total & 32 & $100 \%$ & & $\begin{array}{c}32 \text { Peserta } \\
\text { Dididk (100\%) }\end{array}$ \\
\hline
\end{tabular}

Dari tabel 1 di atas dapat dilihat bahwa, peserta didik yang berada pada kategori sangat aktif tidak ada, kategori aktif 25 orang (78\%), kategori cukup aktif 7 orang (22\%), kurang aktif tidak ada begitu juga dengan siswa yang sangat kurang aktif. Jadi hasil analisis data di atas maka dapat dikatakan bahwa implementasi model pembelajaranan kooperatif tipe NHT efektif untuk meningkatkan aktivitas belajar teknik dasar passing kaki bagian 
dalam, hal ini dapat dilihat dari presentase ketuntasan belajar yang mencapai $78 \%$ (25 orang).

Tabel 2. Hasil Analisis Data Hasil Belajar Aspek Pengetahuan Teknik Dasar Passing Kaki Bagian Dalam pada Siklus I

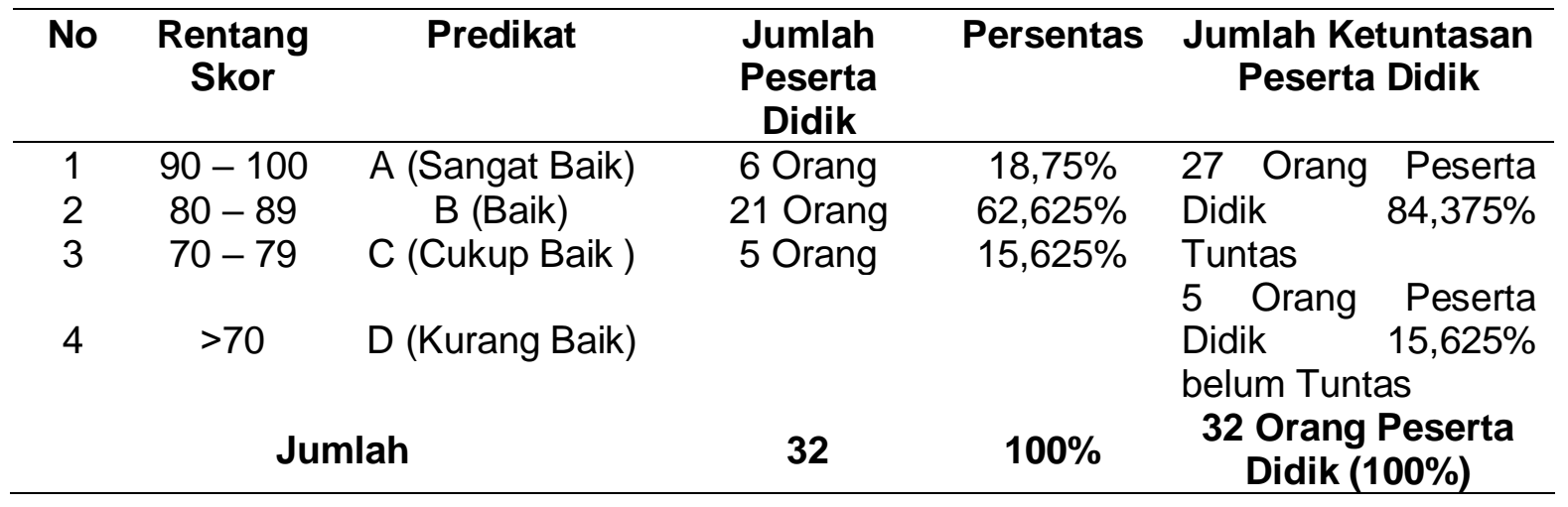

Berdasarkan tabel 2, hasil belajar aspek pengetahuan pada siklus I dengan materi teknik dasar passing kaki bagian dalam, diperoleh data hasil belajar dengan kategori individu sebagai berikut, 6 orang kategori sangat baik (18,75\%), 21 orang peserta didik $(65,625 \%)$ memperoleh nilai dengan kategori baik, 5 orang peserta didik $(15,625 \%)$ memperoleh nlai dengan kategori cukup, dan 0 orang peserta didik $(0 \%)$ memperoleh nilai dengan kategori kurang.

Tabel 3. Hasil Analisis Data Hasil Belajar Aspek Sikap Teknik Dasar Passing Kaki Bagian Luar pada siklus I.

\begin{tabular}{cccccc}
\hline No & Rentang Skor & Predikat & $\begin{array}{l}\text { Jumlah } \\
\text { Peserta } \\
\text { Didik }\end{array}$ & Persentas & $\begin{array}{l}\text { Jumlah Ketuntasan } \\
\text { Peserta Didik }\end{array}$ \\
\hline 1 & $90-100$ & A & 9 Orang & $28,125 \%$ & 32 Orang Peserta \\
2 & $80-89$ & B & 8 Orang & $26,7 \%$ & Didik Tuntas (100\%) \\
3 & $70-79$ & C & - & - & - \\
4 & $>70$ & D & - & - & 32 Orang Peserta \\
Didik (100\%)
\end{tabular}

Berdasarkan di atas, hasil belajar aspek sikap pada siklus I dengan materi teknik dasar passing kaki bagian luar, diperoleh data hasil belajar dengan kategori individu sebagai berikut, peserta didik dengan kategori sangat baik 9 orang peserta didik $(28,125 \%), 23$ orang peserta didik $(71,875 \%)$ memperoleh nilai dengan kategori baik, tidak ada peserta didik dengan kategori cukup, tidak ada peserta didik yang memperoleh nilai dengan kategori kurang.

Tabel 4. Hasil Analisis Data Hasil Belajar Aspek Keterampilan passing menggunakan kaki bagian luar pada siklus I

\begin{tabular}{cccccc}
\hline No & $\begin{array}{c}\text { Rentang } \\
\text { Skor }\end{array}$ & Predikat & $\begin{array}{c}\text { Jumlah } \\
\text { Peserta Didik }\end{array}$ & $\begin{array}{c}\text { Persenta } \\
\text { s }\end{array}$ & $\begin{array}{c}\text { Jumlah Ketuntasan } \\
\text { Peserta Didik }\end{array}$ \\
\hline 1 & $90-100$ & $\begin{array}{c}\text { A (Sangat } \\
\text { Baik) }\end{array}$ & 10 Orang & $31,25 \%$ & $\begin{array}{l}26 \text { Orang Peserta } \\
\text { Didik 81,25\% Tuntas }\end{array}$ \\
\hline
\end{tabular}




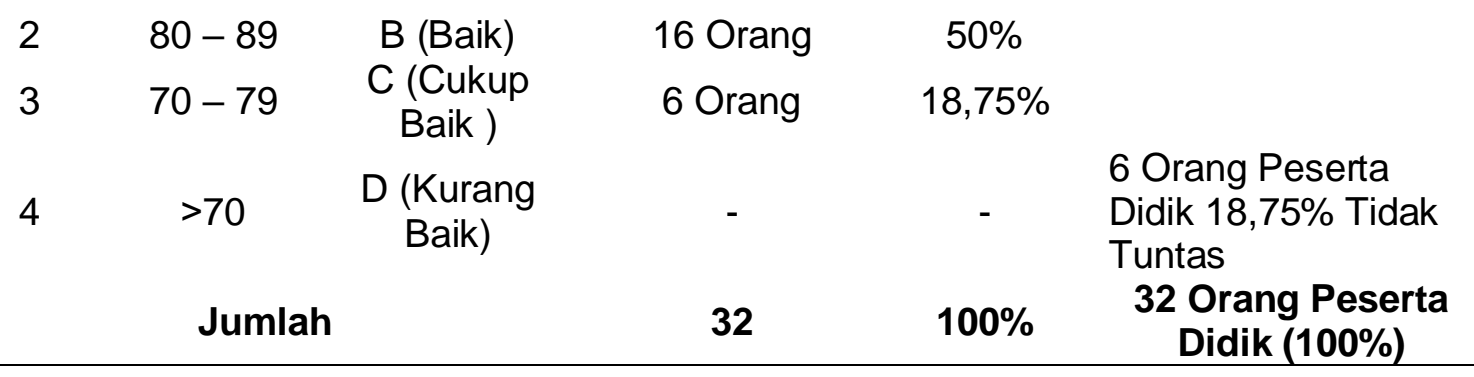

Berdasarkan tabel 4.4, hasil belajar aspek keterampilan pada siklus I dengan materi teknik dasar passing kaki bagian luar, diperoleh data hasil belajar dengan kategori individu sebagai berikut, 10 orang kategori sangat baik $(31,25 \%), 16$ orang $(50,00 \%)$ memperoleh nilai dengan kategori baik, 6 orang $(18,75 \%)$ memperoleh nilai dengan kategori cukup, dan tidak ada peserta didik yang memperoleh nilai dengan kategori kurang.

Tabel 5. Hasil Analisis Data Aktivitas Belajar Teknik Dasar Passing Kaki Bagian Luar pada Siklus II

\begin{tabular}{|c|c|c|c|c|c|}
\hline No & Kriteria & $\begin{array}{l}\text { Jumlah } \\
\text { Peserta } \\
\text { Dididk }\end{array}$ & Persentase & Kategori & Keterangan \\
\hline 1 & $\bar{X} \geq 9$ & 2 & $6,25 \%$ & Sangat aktif & $\begin{array}{l}2 \text { Orang Peserta didk } \\
\text { sangat aktif }(6,25 \%)\end{array}$ \\
\hline 2 & $7 \leq \bar{X}<9$ & 28 & $87,5 \%$ & Aktif & $\begin{array}{l}28 \text { Orang Peserta } \\
\text { Didik Aktif }(87,5 \%)\end{array}$ \\
\hline 3 & $5 \leq \bar{X}<7$ & 2 & $6,25 \%$ & Cukup Aktif & $\begin{array}{l}2 \text { Orang Peserta Didik } \\
\text { Cukup Aktif }(6,25 \%)\end{array}$ \\
\hline 4 & $3 \leq \bar{X}<5$ & - & - & Kurang Aktif & \\
\hline 5 & $\bar{X}<3$ & - & - & $\begin{array}{c}\text { Sangat Kurang } \\
\text { Aktif }\end{array}$ & \\
\hline & Total & 32 & $100 \%$ & & $\begin{array}{c}32 \text { Peserta Didik } \\
(100 \%)\end{array}$ \\
\hline
\end{tabular}

Dari tabel 5 di atas dapat dilihat bahwa, peserta didik yang berada pada kategori sangat aktif 2 orang (6,25\%), kategori aktif 28 orang (87,5\%), kategori cukup aktif 2 orang $(6,25 \%)$, dan tidak ada peserta didik yang berada dalam kategori kurang aktif, dan sangat kurang aktif.

Tabel 6. Hasil Analisis Data Hasil Belajar Aspek Pengetahuan Teknik Dasar Passing Kaki

Bagian Luar pada Siklus II

\begin{tabular}{|c|c|c|c|c|c|}
\hline No & Rentang Skor & Predikat & $\begin{array}{c}\text { Jumlah } \\
\text { Peserta } \\
\text { Didik }\end{array}$ & Persentase & $\begin{array}{c}\text { Jumlah } \\
\text { Ketuntasan } \\
\text { Peserta Didik }\end{array}$ \\
\hline 1 & $90-100$ & $\begin{array}{l}\text { A (Sangat } \\
\text { Baik) }\end{array}$ & 27 Orang & $84,375 \%$ & $\begin{array}{l}32 \text { Orang Peserta } \\
\text { Didik } 100 \% \text { Tuntas }\end{array}$ \\
\hline 2 & $80-89$ & B (Baik) & 5 Orang & $15,625 \%$ & \\
\hline 3 & $70-79$ & $\begin{array}{c}\text { C (Cukup } \\
\text { Baik ) }\end{array}$ & - & - & \\
\hline \multirow[t]{2}{*}{4} & $>70$ & $\begin{array}{l}\text { D (Kurang } \\
\text { Baik) }\end{array}$ & - & - & 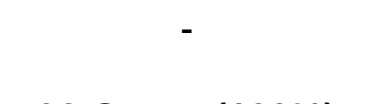 \\
\hline & Jumlah & & 32 & $100 \%$ & 32 Orang $(100 \%)$ \\
\hline
\end{tabular}


Berdasarkan tabel 6, hasil belajar aspek pengetahuan pada siklus II dengan materi teknik dasar passing kaki bagian luar, diperoleh data hasil belajar dengan kategori individu sebagai berikut, 27 Orang Peserta didik (84,375\%) dalam kategori sangat baik, 5 orang peserta didik (15,625\%) memperoleh nilai dengan kategori baik, dan tidak ada peserta didik yang memperoleh nilai dengan kategori cukup dan kurang baik.

Tabel 7. Hasil Analisis Data Hasil Belajar Aspek Sikap Teknik Dasar Passing Kaki Bagian Luar pada Siklus II

\begin{tabular}{cccccc}
\hline No & $\begin{array}{c}\text { Rentang } \\
\text { Skor }\end{array}$ & Predikat & $\begin{array}{c}\text { Jumlah } \\
\text { Peserta } \\
\text { Didik }\end{array}$ & Persentas & $\begin{array}{c}\text { Jumlah Ketuntasan } \\
\text { Peserta Didik }\end{array}$ \\
\hline 1 & $90-100$ & A & 14 Orang & $43,75 \%$ & 30 Orang Peserta Didik \\
2 & $80-89$ & B & 18 Orang & $56,25 \%$ & Tuntas (100\%) \\
3 & $70-79$ & C & - & - & - \\
4 & $>70$ & D & - & - & $\mathbf{3 2 ~ O r a n g ~ P e s e r t a ~}$ \\
& Jumlah & & $\mathbf{3 2}$ & $\mathbf{1 0 0 \%}$ & Didik (100\%) \\
\hline
\end{tabular}

Berdasarkan tabei 7, hasil belajar aspek sikap pada siklus II dengan materi teknik dasar passing kaki bagian luar, diperoleh data hasil belajar dengan kategori individu sebagai berikut 14 orang peserta didik $(43,75 \%)$ dengan kategori sangat baik, 18 orang peserta didik $(56,25 \%)$ memperoleh nilai dengan kategori baik, tidak ada peserta didik yang memperoleh nilai dengan kategori cukup maupun yang memperoleh nilai dengan kategori kurang.

Tabel 8. Hasil Analisis Data Hasil Belajar Aspek Keterampilan Teknik Dasar Passing Kaki Bagian Luar pada Siklus II

\begin{tabular}{|c|c|c|c|c|c|}
\hline No & Rentang Skor & Predikat & $\begin{array}{c}\text { Jumlah } \\
\text { Peserta } \\
\text { Didik }\end{array}$ & Persentase & $\begin{array}{c}\text { Jumlah } \\
\text { Ketuntasan } \\
\text { Peserta } \\
\text { Didik }\end{array}$ \\
\hline 1 & $90-100$ & A (Sangat Baik) & 15 Orang & $33,3 \%$ & Orang \\
\hline 2 & $80-89$ & B (Baik) & 17 Orang & $43,4 \%$ & Peserta Didik \\
\hline 3 & $70-79$ & C (Cukup Baik ) & - & - & $100 \%$ Tuntas \\
\hline 4 & $>70$ & D (Kurang Baik) & - & - & - \\
\hline & Jumlah & & 32 & $100 \%$ & $\begin{array}{l}32 \text { Orang } \\
\text { Peserta Didik } \\
(100 \%)\end{array}$ \\
\hline
\end{tabular}

Berdasarkan tabel 8, hasil belajar aspek keterampilan pada siklus II dengan materi teknik dasar passing kaki bagian luar, diperoleh data hasil belajar dengan kategori individu sebagai berikut, 15 orang peserta didik (46,875\%) dalam kategori sangat baik, 17 orang peserta didik $(53,125 \%)$ dalam kategori baik, dan tidak ada peserta didik yang memperoleh nilai dengan kategori cukup dan kurang. 
Tabel 9. Ringkasan Data Aktivitas Belajar Teknik Dasar Passing Kaki Bagian Luar Peserta Didik Dari Siklus I sampai dengan Siklus II.

\begin{tabular}{|c|c|c|c|c|}
\hline No & Tahapan & $\begin{array}{c}\text { Aktivitas Belajar } \\
\text { Klasikal }\end{array}$ & $\begin{array}{l}\text { Keaktifan Peserta } \\
\text { Didik (Orang) }\end{array}$ & $\begin{array}{c}\text { Peningkatan Aktivitas } \\
\text { Belajar } \\
\text { Siklus I ke Siklus II }\end{array}$ \\
\hline 1. & Siklus I & 7 & $\begin{array}{c}25 \text { orang }(78 \%) \text { Sudah } \\
\text { aktif }\end{array}$ & 5 Orang $(15,7 \%)$ \\
\hline 2. & Siklus II & 7,9 & $\begin{array}{c}30 \text { orang }(93,7 \%) \\
\text { Sudah aktif }\end{array}$ & \\
\hline
\end{tabular}

Berdasarkan Tabel 9, data aktivitas belajar teknik dasar passing kaki bagian luar pada peserta didik kelas XII MIPA 8 SMA Negeri 1 Singaraja dapat disampaikan bahwa, peserta didik yang sudah aktif pada siklus I, 25 orang (78\%). Karena pada siklus I aktivitas peserta didik masih perlu ditingkatkan, sehingga pada siklus II kembali diberikan tindakan. Setelah diberikan tindakan pada siklus II, aktivitas belajar peserta didik meningkat menjadi 30 orang $(93,7 \%)$ yang aktif . dari siklus I ke Siklus II terjadi peningkatan sebanyak 5 orang $(15,7 \%)$.

Tabel 10. Ringkasan Data Hasil Belajar Passing Menggunakan Kaki Bagian Luar Aspek Pengetahuan Peserta Didik Kelas XII MIPA 8 SMA Negeri 1 Singaraja dari Siklus I sampai dengan Siklus II.

\begin{tabular}{|c|c|c|c|c|}
\hline No & Tahapan & $\begin{array}{l}\text { Persentase } \\
\text { Ketuntasan } \\
\text { Hasil Belajar }\end{array}$ & $\begin{array}{c}\text { Ketuntasan Peserta } \\
\text { Didik }\end{array}$ & $\begin{array}{l}\text { Peningkatan Hasil } \\
\text { Belajar Aspek } \\
\text { Pengetahuan } \\
\text { Siklus I ke Siklus II }\end{array}$ \\
\hline 1. & Siklus I & $\begin{array}{c}27 \text { Orang } \\
(84,3 \%)\end{array}$ & Tuntas & 5 Orang $(15.7 \%)$ \\
\hline 2. & Siklus II & $\begin{array}{c}32 \text { Orang } \\
(100 \%)\end{array}$ & Tuntas & \\
\hline
\end{tabular}

Berdasarkan tabel 4.10 hasil analisis data hasil belajar aspek pengetahuan teknik dasar passing kaki bagian luar pada peserta didik kelas XII MIPA 8 SMA Negeri 1 Singaraja dapat disampaikan bahwa, persentase ketuntasan hasil belajar aspek pengetahuan peserta didik pada siklus I sebesar 27 orang (84,3\%). Karena pada siklus I masih ada peserta didik yang belum tuntas maka diberikan tindakan pada siklus II. Setelah diberikan tindakan pada siklus II ketuntasan hasil belajar peserta didik meningkat 5 orang $(15,7)$ dari siklus I, sehingga jumlah ketuntasan hasil belajar aspek pengetahuan peserta didik pada siklus II menjadi 32 orang (100\%). Dari hasil analisis data tersebut, dapat dilihat peningkatan ketuntasan hasil belajar aspek pengetahuan yang terjadi dari siklus I ke siklus II sebanyak 5 orang $(15,7 \%)$. 
Tabel 11. Ringkasan Data Hasil Belajar Teknik Dasar Passing Kaki Bagian Luar Aspek Sikap Peserta Didik Kelas XII MIPA 8 SMA Negeri 1 Singaraja dari Siklus I sampai dengan Siklus II.

\begin{tabular}{ccccc}
\hline No & Tahapan & $\begin{array}{c}\text { Persentase } \\
\text { Ketuntasan Hasil } \\
\text { Belajar }\end{array}$ & $\begin{array}{c}\text { Ketuntasan Peserta } \\
\text { Didik }\end{array}$ & $\begin{array}{c}\text { Peningkatan Hasil } \\
\text { Belajar Aspek Sikap } \\
\text { Siklus I ke Siklus II }\end{array}$ \\
\hline 1. & Siklus I & $\begin{array}{c}\text { 32 Orang (100\%) } \\
\text { 32 Orang (100\%) }\end{array}$ & $\begin{array}{c}\text { Tuntas } \\
\text { Tuntas }\end{array}$ & Siklus II \\
\hline
\end{tabular}

Berdasarkan tabel 4.11 hasil analisis data hasil belajar aspek sikap teknik dasar passing kaki bagian luar pada peserta didik kelas XII MIPA 8 SMA Negeri 1 Singaraja dapat disampaikan bahwa, tingkat ketuntasan hasil belajar aspek sikap peserta didik pada siklus I sebanyak 32 orang (100\%). Karena pada siklus I tidak ada peserta didik yang belum tuntas, apalagi ketuntasan peeserta didik masih dalam kategori cukup, maka diberikan tindakan pada siklus II. Setelah diberikan tindakan pada siklus II ketuntasan hasil belajar aspek sikap teknik dasar passing kaki bagian luar peserta didik masih tetap 32 orang siswa lulus $(100 \%)$.

Tabel 4.12 Ringkasan Data Hasil Belajar Teknik Dasar Passing Kaki Bagian Luar Aspek Keterampilan Peserta Didik Kelas XII MIPA 8 SMA Negeri 1 Singaraja dari Siklus I sampai dengan Siklus II.

\begin{tabular}{|c|c|c|c|c|}
\hline No & Tahapan & $\begin{array}{c}\text { Persentase } \\
\text { Ketuntasan Hasil } \\
\text { Belajar }\end{array}$ & $\begin{array}{c}\text { Ketuntasan Peserta } \\
\text { Didik }\end{array}$ & $\begin{array}{l}\text { Peningkatan Hasil } \\
\text { Belajar Aspek } \\
\text { Keterampilan } \\
\text { Siklus I ke Siklus II }\end{array}$ \\
\hline $\begin{array}{l}1 . \\
2 .\end{array}$ & $\begin{array}{l}\text { Siklus I } \\
\text { Siklus II }\end{array}$ & $\begin{array}{c}26 \text { Orang }(81,25 \%) \\
30 \text { Orang }(100 \%)\end{array}$ & $\begin{array}{l}\text { Tuntas } \\
\text { Tuntas }\end{array}$ & 6 Orang $(18,7 \%)$ \\
\hline
\end{tabular}

Berdasarkan tabel 4.12 hasil analisis data hasil belajar aspek keterampilan teknik dasar passing kaki bagian luar pada peserta didik kelas XII MIPA 8 SMA Negeri 1 Singaraja dapat disampaikan bahwa, tingkat ketuntasan hasil belajar aspek keterampilan peserta didik pada siklus I sebanyak 26 orang $(81,25 \%)$. Karena pada siklus I masih ada peserta didik yang belum tuntas, apalagi ketuntasan peserta didik masih dalam kategori cukup, maka diberikan tindakan pada siklus II. Setelah diberikan tindakan pada siklus II ketuntasan hasil belajar aspek keterampilan teknik dasar passing kaki bagian dalam peserta didik meningkat sebanyak 6 orang $(18,7 \%)$ dari siklus I, sehingga jumlah ketuntasan hasil belajar aspek keterampilan peserta didik pada siklus II menjadi 32 orang (100\%). Dari hasil analisis data tersebut, dapat dilihat peningkatan ketuntasan hasil belajar aspek keterampilan yang terjadi dari siklus I ke siklus II sebanyak 6 orang $(18,7 \%)$.

Berdasarkan hasil analisis data dari implementasi model pembelajaran kooperatif tipe NHT yang bertujuan untuk meningkatkan aktivitas dan hasil belajar teknik dasar passing kaki bagian luar, dimana hasil penelitian aktivitas belajar peserta didik pada siklus I terhadap pembelajaran PJOK khususnya pada materi teknik dasar passing kaki bagian luar secara klasikal berada pada kategori cukup aktif. Dengan memperhatikan aktivitas dan hasil belajar teknik dasar passing kaki bagian luar siklus I, peneliti melanjutkan ke siklus II dengan melihat permasalahan-permasalahan pada siklus I. Hal ini terbukti dari refleksi dari siklus I yang masih terdapat permasalahan-permasalahan dalam pelaksanaan tindakan.

Adapun permasalahan-permasalahan yang dihadapi dalam pembelajaran pada siklus I yaitu: (1) peserta didik kurang mendengarkan penjelasan dari peneliti tentang teknik dasar passing kaki bagian luar (2) peserta didik kurang memperhatikan demonstrasi yang 
diperagakan oleh peneliti tentang teknik dasar passing kaki bagian luar, (3) peserta didik kurang menaruh minat dan bersemangat dalam melakukan gerakan teknik dasar passing kaki bagian luar, (4) peserta didik belum berani mengajukan pertanyaan dan mengemukakan pendapat karena takut dan malu ditertawakan temanya jika salah terkait teknik dasar passing kaki bagian luar, (5) kurangnya pemahaman peserta didik terhadap model pembelajaran kooperatif tipe $\mathrm{NHT},(6)$ peserta didik kurang bersemangat dan besungguh-sungguh dalam melakukan teknik dasar passing kaki bagian luar, (7) kurangnya kesempatan peserta didik dalam melakukan gerakan teknik dasar passing kaki bagian luar sehingga hasilnya kurang maksimal.

Berdasarkan permasalahan-permasalahan yang dihadapi pada siklus I tersebut maka adapun solusinya yaitu: (1) bagi peserta didik yang kurang mendengarkan saat pemberian materi, peserta didik tersebut akan dipanggil kedepan untuk menjelaskan materi yang sudah diberikan, (2) memberikan penghargaan berupa nilai plus bagi peserta didik yang bersungguh-sungguh pada saat melakukan gerakan teknik dasar passing kaki bagian luar sehingga pandangan dapat mengarah ke depan, (3) memberikan pertanyaan mengenai materi yang sudah disampaikan agar peserta didik tidak ragu-ragu dalam menjawab pertanyaan yang di berikan, (4) mengimplementasi model pembelajaran kooperatif tipe NHT pada peserta didik secara lebih jelas dengan memberikan lembaran tahapan-tahapan pembelajaran kooperatif tipe NHT, (5) memberikan motivasi agar peserta didik menjadi lebih bersemangat dan bersungguh-sungguh dalam mengikuti pembelajaran pada siklus II tentang teknik dasar passing kaki bagian luar, (6) membariskan peserta didik 2 bersaf agar peserta didik yang berada di belakang dapat memperhatikan lebih jelas mengenai materi yang disampaikan, (7) membagi peserta didik menjadi jumlah kelompok yang lebih banyak sehingga jumlah peserta didik dalam satu kelompok lebih sedikit sehingga kesempatan dalam melakukan gerakan di setiap peserta didik menjadi lebih banyak.

Pembelajaran pada siklus II berlangsung sangat kondusif, peserta didik sudah mengetahui dan mampu beradaptasi dengan model pembelajaran kooperatif tipe NHT. Hal ini terlihat dari aspek aktivitas belajar peserta didik, saat peneliti memperagakan gerakan tidak lagi hanya menonton tetapi aktif bertanya terhadap penjelasan peneliti di setiap tahap gerakan yang diperagakan oleh peneliti. Rata-rata aktivitas belajar teknik dasar passing kaki bagian luar secara klasikal tergolong aktif. Sedangakan untuk penguasaan materi teknik dasar passing kaki bagian luar berada dalam kategori baik. Peningkatan ini tidak terlepas dari implementasi model pembelajaran kooperatif tipe NHT secara optimal dengan perbaikan-perbaikan pembelajaran sesuai dengan kekurangan-kekurangan yang terjadi pada siklus sebelumnya.

Berdasarkan uraian di atas, berarti tingkat ketuntasan hasil belajar teknik dasar passing kaki bagian luar pada siklus II sudah memenuhi standar ketuntasan secara klasikal yaitu sebesar 82 sesuai dengan KKM di SMA Negeri 1 Singaraja. Peningkatan aktivitas dan hasil belajar pada siklus II dikarenakan: 1) penggunaan model pembelajaran kooperatif tipe NHT dengan pembelajaran berkelompok sudah dipahami oleh peserta didik dan 2) peneliti melakukan perbaikan berdasarkan kendala-kendala yang dialami pada siklus I. Meskipun pelaksanaan siklus II dinyatakan berhasil, tetapi masih terdapat kendala-kendala yang dihadapi saat penerapan model pembelajaran kooperatif tipe NHT, yaitu: terbatasnya waktu pelaksanaan penelitian sehingga peserta didik kekurangan waktu untuk lebih memahami tahapan-tahapan model pembelajaran yang peneliti terapkan. Dengan adanya kendala tersebut solusi yang peneliti sarankan kepada guru yaitu untuk selanjutnya agar lebih sering menerapkan model pembelajaran kooperatif tipe NHT dalam pembelajaran PJOK, sehingga peserta didik akan semakin paham dengan struktur pembelajaran dalam model pembelajaran kooperatif tipe NHT. Berdasarkan data analisa hasil uraian di atas, aktivitas dan hasil belajar meningkat dikarenakan: (1) Peserta didik lebih aktif dalam mengikuti suatu proses pembelajaran dalam melakukan interaksi dengan teman sehingga pembelajaran lebih aktif dan tidak satu arah, (2) Timbulnya kerjasama antar peserta didik dengan peserta didik, tim atau teman didalam kelompoknya dapat menyelesaikan tugas gerak yang diberikan oleh guru, (3) Peserta didik memiliki rasa tanggung jawab sehingga peserta didik 
dapat mengerjakan tugas dengan baik dalam suatu proses pembelajaran di dalam kelompoknya, (4) Peserta didik mengamati apa yang dicontohkan oleh guru atau dari orang lain dalam suatu proses pembelajaran, (5) Rasa percaya diri peserta didik dalam melaksanakan tugas gerak yang diberikan oleh guru.

Berdasarkan penelitian yang sudah dilakukan, adapun keterbatasan dalam melakukan penelitian ini yaitu: keterbatasan waktu pelaksanaan penelitian yang dilakukan 2 siklus, agar tidak mengganggu dari kurikulum sekolah yang sudah dibuat. Berdasarkan hasil penelitian yang telah peneliti lakukan serta teori-teori pendukung hasil penelitian yang telah dipaparkan di atas dapat disimpulkan bahwa penerapan model pembelajaran kooperatif tipe NHT dapat meningkatkan aktivitas dan hasil belajar teknik dasar passing kaki bagian luar pada peserta didik kelas XII MIPA 8 SMA Negeri 1 Singaraja Tahun Pelajaran 2018/2019. Penelitian yang sudah dilaksanakan ini tidaklah selalu berjalan dengan lancar sesuai dengan yang diharapkan dan yang sudah direncanakan. Karena ada kendala-kendala yang dihadapi peneliti dalam menjalankan penelitian ini. Adapun kendala-kendala yang dihadapi adalah: (a) jumlah alat-alat pendukung yang kurang dari jumlah kelompok belajar yang sudah direncanakan, (b) respon peserta didik untuk memahami materi lambat sehingga harus dijelaskan berulang-ulang.

Dari kendala-kendala yang dihadapi tersebut adapun yang dilakukan peneliti untuk memecahkannya sehingga penelitian yang dilakukan dapat berjalan dengan lancar diantaranya adalah: (a) menggunakan lapangan sekolah yang sudah ada dan alat yang dimiliki oleh peserta didik, (b) menggunakan lantai aula untuk melakukan gerakan sikap lilin untuk kekurangan Matras, dan (c) menjelaskan kembali secara berulang-ulang materi yang belum dimengerti.

\section{Simpulan}

Berdasarkan hasil analisis data dan pembahasan di atas dapat disimpulkan bahwa 1) Aktivitas belajar teknik dasar passing kaki bagian dalam meningkat melalui implementasi model pembelajaran kooperatif tipe NHT pada siswa kelas XII MIPA 8 SMA Negeri 1 Singaraja tahun pelajaran 2018/2019; 2) Hasil belajar teknik dasar passing kaki bagian dalam meningkat melalui implementasi model pembelajaran kooperatif tipe NHT pada siswa kelas XII MIPA 8 SMA Negeri 1 Singaraja tahun pelajaran 2018/2019.

\section{Daftar Pustaka}

Dimiyati dan Mudjiono. 2006. Belajar dan Pembelajaran. Jakarta: Rineka Cipta.

Hamalik. 2008. Proses Belajar Mengajar. Jakarta: Bumi Aksara.

Kanca, I Nyoman. 2010. Metodologi Penelitian Keolahragaan. Singaraja: Universitas Pendidikan Ganesha.

Nurhadi. 2004. Pembelajaran Kontekstual dan Penerapannya dalam KBK. Malang: Universitas Negeri Malang.

Nurkancana dan Sunartana. 1990. Evaluasi Hasil Belajar. Surabaya: Usaha Nasional.

Permendikbud no 65. 2013. Tentang Standar Isi Pendidikan Dasar dan Menengah. Jakarta: Kemendikbud

Sudjana. 2004. Penilaian Hasil Proses Belajar Mengajar. Bandung: Remaja Rosdakarya.

Sugiyanto. 1998. Perkembangan dan Belajar Motorik. Jakarta:Departemen Pendidikan dan Kebudayaan.

Trianto. 2007. Model-Model Pembelajaran Inovatif. Jakarta: Prestasi Pustaka Publisher.

Undiksha. 2013. Pedoman Penulisan Skripsi dan Tugas Akhir. Singaraja: Departemen Pendidikan Nasional Universitas Pendidikan Ganesha. 